\title{
Impact of indoxacarb and sulphur formulation on aphid and three specific predators in Okra fields
}

\author{
M. A. Gesraha* (1D and Amany R. Ebeid
}

\begin{abstract}
Background: For the sake of environmental safety, many new insecticide generations developed. Sulphur formulations and other botanicals or formulated synthetic insecticides were recommended in many integrated pest management programs to protect, particularly, edible vegetables and fruit trees from insect and mite pests as well as plant pathogenic diseases. Such formulations, at the recommended application rates, proved to be safer for mammals. Regarding their safety to beneficial arthropods, diversified results were reported. This study was designed to investigate and evaluate the impact of indoxacarb and sulphur formulation against some natural enemies naturally prevailing in some vegetable crops.

Results: Application of indoxacarb and sulphur formulation in Okra fields to control aphid was carried out. The adverse effects of these applications against some important predators were investigated. The obtained results revealed that indoxacarb was more effective than sulphur application in all treatments. At the end of the experiment, the percentages of population reductions of Coccinella indoxacarb treatment reached $\approx 92$ and $76 \%$ for larvae and adults, respectively. The corresponding figures for Chrysoperla were $\approx 79$ and $82 \%$ for larvae and adults, respectively. Indoxacarb-induced reduction in the Paederus population reached about $80 \%$, while sulphur formulation had negative effects. Both indoxacarb and sulphur formulations were harmful to the aphid, inducing about 97 and 26\% reduction, respectively, for the mean number of aphid populations.

Conclusion: It could be concluded that indoxacarb is more hazardous towards different natural enemies prevailing naturally in open fields at anywhere season round the year, and care must be in consideration when we choose and select some insecticides to kill or to eradicate pests and simultaneously conserve the natural enemies.
\end{abstract}

Keywords: Indoxacarb, Sulphur formulation, Okra fields, Natural enemies

\section{Background}

It is well known that aphids induced serious damages to many vegetables and crops. Since aphid is a piercingsucking insect pest, it is feeding on plant sap inducing loss in leaves qualities, transferring plant viruses, building up fungus mildew and finally destroying leaves. Many efforts were carried out to manage this pest. Using different chemical and/or botanical insecticides, nonetheless,

*Correspondence: mgesraha@gmail.com

Pests and Plant Protection Department, Agricultural and Biological

Researches Division, National Research Centre, Dokki, Cairo, Egypt induced the drawbacks. Herein, we will speak about three important natural enemies prevailing in almost all crop and vegetable fields. In this regard, many research studies were carried out to protect either plant and/or natural enemies from the adverse effects of pesticides (Yada 1989 and Meena et al. 2002, Awasthi et al. 2013; Zuo et al. 2016).

Coccinella undecimpunctata $\mathrm{L}$. is a very important predator that feeds principally on aphids. Given its greediness to these pests. C. undecimpunctata offers an interesting perspective as a control agent in the context of Integrated Pest Management (IPM) (ElHag 1992; 
ElHag and Zaitoon 1996; Zaki et al. 1999; Moura et al. 2006; Cabral et al. 2009). Recent studies showed that, in general, pirimicarb and pymetrozine pesticides had no adverse effects on the biological features (developmental time, fecundity, fertility, percentage of egg hatchability) of immature and/or adult stages of Coccinella when sprayed to control insect pests, which makes these chemicals potentially suitable to use in combination with coccinellids for integrated control of sucking pests (Cabral et al. 2008 2011). On the other hand, Galven et al. (2005, 2006) reported harmful effects of spinosad and indoxacarb to the lady beetle, Harmonia axyridis (Pallas).

As for the side effects on the Green lacewing, Chrysoperla carnea (Stephens) that considered one of the cosmopolitan important predators of arthropod pests of many crops. The larvae voraciously feed on many soft-bodied arthropods including eggs and early instars of mites, lepidopterans, coleopterans and homopterans (Carnard and Principi 1984). This predator can be found in orchards and farms. In some areas, it is mass-reared and released as a biological control agent (Azma and Mirabzadae 2004). At present, the application of pesticides is one of the most effective strategies of pest control. Considering chemical control side effects such as the development of resistance in pests, environment pollution and destruction of natural enemies and nontarget organisms, their application can be reduced using the integrated pest management programs (Croft 1990). Therefore, the selection of pesticides shall be made carefully to maximize the effects on target pests and minimize deleterious effects on beneficial organisms.

Due to the physiological similarities among pest arthropods and their natural enemies, insecticides usually cause severe mortality in both groups. Moreover, insecticides disrupt the feeding interactions in the ecosystems and in some cases increase the secondary pests' population. Determining the effects of pesticides on natural enemies can be useful in the appropriate selection of these compounds for integrated pest management programs. Some researches were carried out on C. carnea as an important predator in many cropping systems, where imidacloprid, indoxacarb and endosulfan are applied and the lethal and sublethal effects of these insecticides were investigated (Metcalf 1986; Croft 1990).

The third important natural enemy is the rove beetle; Paederus alfierii Koch. (Coleoptera: Staphylinidae) is well known among natural enemies in Egypt as an important predator of agricultural insect pests, and it is used as an essential agent in the integrated pest management programs. The population level of the rove beetle was relatively low in general (Tawfik et al. 1976).

This work aimed to explore the adverse effects of the tested insecticides (sorell 98\% and indoxacarb (Avaunt
$150 \mathrm{SC})$ ) when applied to control aphids infesting Okra plants, on the population abundance of three important insect predators (Coccinella undecimpunctata, Chrysoperla carnea, and rove beetles, Paederus alfierii).

\section{Methods \\ Insecticides used}

1. Indoxacarb: Indoxacarb was produced by DuPont Company (Avaunt 150 SC, 1 L). Active ingredient: indoxacarb $14.5 \%$. The recommended concentration is $150 \mathrm{~g} / \mathrm{L}$ added to $1500 \mathrm{~L}$ water/hectare $=600 \mathrm{~L}$ water $/$ Feddan $(1$ hectare $=2.381$ Feddan.

2. Sulphur formulation (agricultural sorell 98\%) was produced by Kafr El-Zayat Company, for Chemical Insecticides Production, Egypt, which was recommended by the Ministry of Agriculture, Egypt as a protectant for vegetable crops against some plant diseases and piercing-sucking pests (aphids, whiteflies, thrips, leafhoppers and mites); the recommended dose is $30 \mathrm{Kg} /$ Feddan. The dusting of sulphur was carried out using Chapin 5000 16-oz Hand Rose and Plant Duster Sprayer-Model \#5000 duster 30-day post-sowing.

\section{Tested insects}

1. Ladybird, Coccinella undecimpunctata Linnaeus (larvae and adults).

2. Lacewing, Chrysoperla carnea Stephens (larvae and adults).

3. Rove beetles, Paederus alfierii Fabricius (larvae and adults).

4. Aphids, Aphis gossypii Glover (nymphs and adults).

\section{Field application}

Field experiments were carried out (as described by Gesraha et al. 2019; Gesraha and Ebeid 2019 and Matter et al. $2018,2019)$ in two separate fields.

Experiments were conducted at Belbeis region, ElSharkia Governorate, Egypt (coordinates: $30^{\circ} 25^{\prime} 18^{\prime \prime}$ $\mathrm{N}-31^{\circ} 33^{\prime} 33^{\prime \prime} \mathrm{E}$ ), in already-cultivated Okra field, where all agricultural practices were carried out as usual by their owner farmer during June 2018. Two infested areas (ca. $300 \mathrm{~m}^{2}$ each) were chosen to execute the experiment; one for indoxacarb and the other for sorell 98\% application to control the aphid, Aphis gossypii infestation. Another two areas were chosen and serve as a control (check). Each area was divided into four equal plots (ca. $75 \mathrm{~m}^{2}$ ). The mean number of aphid and each tested natural enemy/50 plant/plot/time interval was recorded 
at five time intervals, i.e., before application $(-2 \mathrm{~h}), 2-\mathrm{h}$, 24-h, 48-h and 7-day post-application. Percentages of reduction in infestation were calculated. The abovementioned statement was applied also for check plots.

\section{Statistical analysis}

A randomized complete block design was applied. MSTAT-C Statistical Package (Freed 1985) Computer program was used. All data were subjected to analysis of variance ANOVA F test. Mean values were significantly separated using Duncan's Multiple Range Test (Duncan 1955). Student t test was applied to discriminate between each treated plot and its control. Percentages of reduction in infestation were calculated according to Henderson and Tilton equation (Henderson and Tilton 1955).

\section{Results}

\section{Coccinella larval treatments}

The application of both insecticides revealed that statistically nonsignificant differences between the treated and the control plots of ladybird larvae at $2 \mathrm{~h}$ before application were observed as referred by the calculated $F$ value $\left(F_{3,12}=0.479^{\mathrm{NS}}, P=0.703\right)$ (Table 1$)$. Two hours post-application interval, the corresponding figure was in contrast, where there was a highly significant difference between the mean numbers of the treated ladybird larvae $\left(F_{3,12}=20.080^{* * *}, P=0.000\right)$. It was observed that indoxacarb treatment induced a higher effect compared to the sulphur treatment and the tow controls (Table 1). In another view, nonsignificant differences were observed between sulphur treatment and its control $\left(T=0.012^{\mathrm{NS}}\right.$, $d f=6)$, with the same nonsignificant difference in the case of indoxacarb and its control $\left(T=1.359^{\mathrm{NS}}, d f=6\right)$ (Table 1, Fig. 1).

Nearly, the same trends were observed for 24-h-, 48-hand 7-day-interval post-treatment $\left(F_{3,12}=137.818^{* *}\right.$, $372.444^{* * *}, 123.141^{* *}$ ), respectively (Table 1 ).

It is obvious that on comparing sulphur treatment and its control, there was an nonsignificant difference at all inspection time intervals, except after 7-day interval $\left(T=6.724^{* * *}\right)$ (Table 1, Fig. 1), where the mean number of ladybird populations in treated plots was more than that in control plots. That may be referred to as the disappearance of sulphur application effects.

For indoxacarb, significant differences were observed in all check-ups time intervals between treated and control plots except that before application (Table 1, Fig. 1). Comparing the Coccinella populations in different time intervals revealed that an nonsignificant difference was observed in sulphur treatments $\left(F=2.584^{\mathrm{NS}}\right.$, $P=0.061$ ), i.e., sulphur application had no negative effect on Coccinella larvae, specifically, population

Table 1 Effect of indoxacarb and sorell $98 \%$ treatments on the population density of ladybird larvae and adults

\begin{tabular}{|c|c|c|c|c|c|c|c|}
\hline \multirow{2}{*}{$\begin{array}{l}\text { Inspection } \\
\text { intervals (h) }\end{array}$} & \multicolumn{6}{|l|}{ Treatments } & \multirow{2}{*}{$\begin{array}{l}F \text { value } 1 \\
(d f=3,12)\end{array}$} \\
\hline & Sulphur & Sulphur control & $T$ value $d f=6$ & Indoxacarb & $\begin{array}{l}\text { Indoxacarb } \\
\text { control }\end{array}$ & $T$ value $d f=6$ & \\
\hline & \multicolumn{7}{|c|}{ Coccinella larvae mean $\pm S E$} \\
\hline-2 & $37.00 \pm 1.87 \mathrm{a} A \mathrm{~A}$ & $38.00 \pm 4.32 \mathrm{a} A \mathrm{~A}$ & $0.212^{\text {NS }}$ & $39.00 \pm 1.41 \mathrm{a} A \mathrm{~A}$ & $41.00 \pm 0.41 \mathrm{a} B C \mathrm{~A}$ & $01.359^{\text {NS }}$ & $00.479^{\text {NS }}$ \\
\hline+2 & $38.00 \pm 0.71 b A_{A}$ & $38.00 \pm 1.41 \mathrm{~b} \mathrm{~A} \mathrm{~A}$ & $0.000^{\text {NS }}$ & $31.00 \pm 1.08 C B$ B & $42.00 \pm 0.71 \mathrm{a} B \mathrm{~A}$ & $08.521 * *$ & $20.080^{* *}$ \\
\hline+24 & $38.00 \pm 2.16 \mathrm{~b} \mathrm{~A} \mathrm{~A}$ & $41.00 \pm 1.08 \mathrm{~b} A_{\mathrm{A}}$ & $1.964^{\text {NS }}$ & $12.00 \pm 1.08 C_{C} C_{B}$ & $47.00 \pm 1.41 \mathrm{a} A \mathrm{~A}$ & $19.668 * *$ & $173.818^{* *}$ \\
\hline+48 & $40.00 \pm 1.41 \mathrm{a} A \mathrm{~A}$ & $37.00 \pm 0.41 \mathrm{~b} A \mathrm{~A}$ & $2.038^{\text {NS }}$ & $05.00 \pm 0.41 C D B$ & $38.00 \pm 0.82 a b C_{A}$ & $36.150 * *$ & $372.444^{* *}$ \\
\hline+7 days & $44.00 \pm 2.55 \mathrm{a} A \mathrm{~A}$ & $26.00 \pm 0.82 \mathrm{~b} B$ B & $6.724 * *$ & $02.00 \pm 0.71 C D$ B & $27.00 \pm 1.41 \mathrm{~b} D \mathrm{~A}$ & $15.811 * *$ & $123.414^{* *}$ \\
\hline$F$ value $2(d f=4,15)$ & $2.584^{\mathrm{NS}}$ & $7.390^{* *}$ & & $267.700^{* *}$ & $52.031^{* *}$ & & \\
\hline \multirow[t]{2}{*}{$\%$ reduction } & $+73.81 \%$ & & & $-92.21 \%$ & & & \\
\hline & \multicolumn{7}{|c|}{ Coccinella adults mean $\pm \mathrm{SE}$} \\
\hline-2 & $16.00 \pm 2.16 \mathrm{a} A \mathrm{~A}$ & $17.00 \pm 0.70 \mathrm{a} B \mathrm{~A}$ & $00.440^{\text {NS }}$ & $15.00 \pm 1.10 \mathrm{a} A \mathrm{~A}$ & $16.00 \pm 0.82 \mathrm{a} C_{A}$ & $00.739^{\text {NS }}$ & $00.381 N S$ \\
\hline+2 & $07.00 \pm 1.47 C B$ B & $28.00 \pm 1.08 \mathrm{a} A \mathrm{~A}$ & $11.602 * *$ & $08.00 \pm 0.83 b$ B в & $20.00 \pm 0.82 \mathrm{a} A \mathrm{~A}$ & $10.392^{* *}>$ & $87.071^{* *}$ \\
\hline+24 & $09.00 \pm 0.74 C B$ B & $31.00 \pm 1.10 \mathrm{a} A \mathrm{~A}$ & $17.041 * *$ & $05.00 \pm 0.41 b C_{B}$ & $23.00 \pm 1.46 \mathrm{a} A \mathrm{~A}$ & $11.784^{* *}>$ & $146.667^{* *}$ \\
\hline+48 & $14.00 \pm 1.46 \mathrm{~b} \mathrm{~A} \mathrm{~A}$ & $19.00 \pm 1.07 \mathrm{a} B \mathrm{~A}$ & $02.739^{*}>$ & $02.00 \pm 0.00 \mathrm{~b} D$ в & $18.00 \pm 1.23 \mathrm{a} C_{\mathrm{A}}$ & $13.064^{* *}>$ & $50.414^{* *}$ \\
\hline+7 days & $18.00 \pm 1.22 \mathrm{a} A \mathrm{~A}$ & $11.00 \pm 1.10 b C_{B}$ & $04.287 * *$ & $02.00 \pm 0.44 \mathrm{~b} D$ в & $09.00 \pm 0.40 \mathrm{a} D \mathrm{~A}$ & $12.124^{* *}>$ & $57.778^{* *}$ \\
\hline$F$ value $2(d f=4,15)$ & $9.864^{* *}$ & $65.032^{* *}$ & & $67.615^{* *}$ & $26.806^{* *}$ & & \\
\hline$\%$ reduction & $+73.86 \%$ & & & $-76.30 \%$ & & & \\
\hline
\end{tabular}

\footnotetext{
** highly significant, * significant, NS nonsignificant

In horizontal rows, means followed with different small letters are statistically different $(P>0.5)$ ( $F$ value 1$)$

In horizontal rows, per each treatment, means followed with different small capital letters are statistically different $(P>0.5)(T$ value $)$

In vertical columns, means followed with different capital Italic letters are statistically different $(P>0.5)(F$ value 2$)$
} 

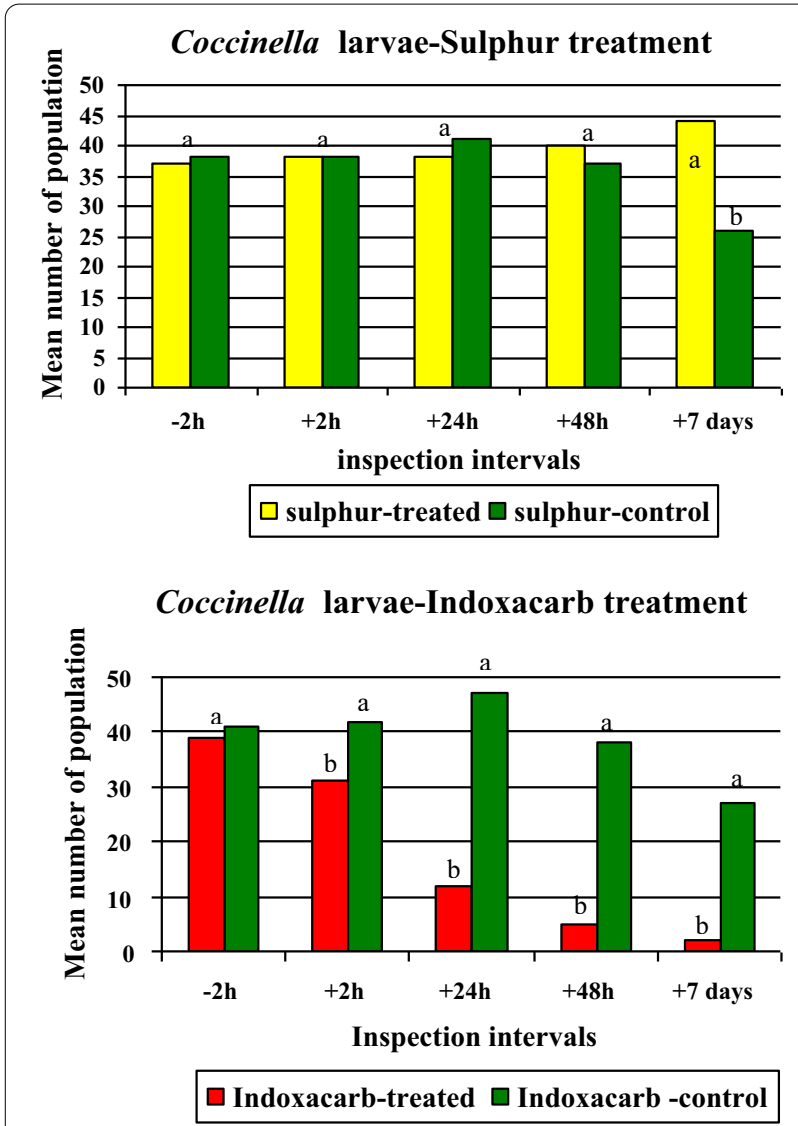

Fig. 1 Effect of indoxacarb and sorell 98\% applications on the abundance of Coccinella larvae. Significant differences were calculated separately for each interval

abundance; it is worthy to indicate that an increment was noticed in the mean population number $(\approx 74 \%)$, whereas the corresponding figure for indoxacarb was the opposite $\left(F=267.700^{* * *}, P=0.000\right)$ for treated plots and $\left(F=52.031^{* * *}, P=0.000\right)$ for control plots, gaining a reduction in ladybird larval population by $\approx 92 \%$ (Table 1). Figure 1 explains the statistical differences between sulphur and/or indoxacarb treatments and their control.

\section{Coccinella adult treatment}

Data in Table 1 demonstrate that applying the sulphur formulation to control Aphis gossypii in the Okra field somewhat negatively affects the population number of beetle's adult throughout all inspection intervals except at the beginning of the experiment, where a significant difference was observed between treated and control plots (Table 1 and Fig. 1). Also, there was an increment in the adult population reached $\approx 74 \%$ (Table 1 ), which means that the sulphur application had negative effects on beetle adults.

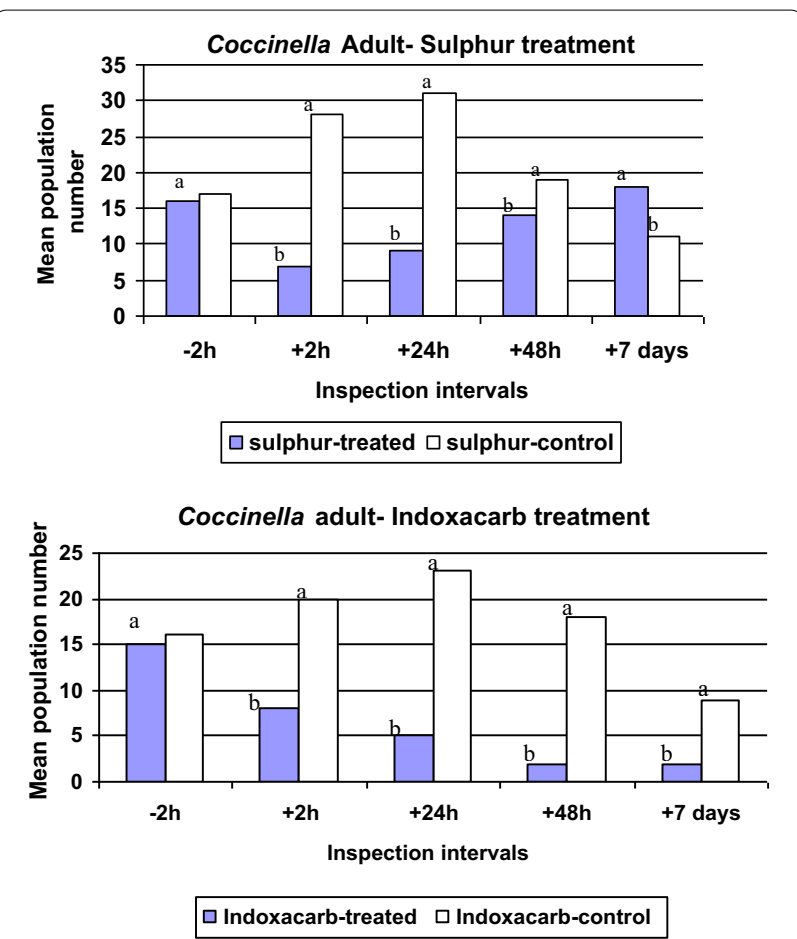

Fig. 2 Effect of indoxacarb and sorell 98\% applications on the abundance of Coccinella adult. Significant differences were calculated separately for each interval

Indoxacarb in general reflects an opposite figure, where it adversely affects the population number of Coccinella adults, gaining $\approx 76 \%$ population reduction. Highly significant differences within time intervals, and between treated and control plots (Table 1 and Fig. 2).

\section{Chrysoperla larval treatments}

As for Lacewings' predator, it was observed in general that the mean number of prevailing larvae was less on average than that of ladybird. Almost the same figure of the abundance of Chrysoperla larvae post-insecticides application bore a resemblance to that in the case of ladybird, whereas indoxacarb application affected roughly the mean numbers of the treated larval population, where the calculated $F$ values in each check time interval were as follows $\left(F_{3,12}=1.429^{\mathrm{NS}}, 6.533^{* *}\right.$, $\left.46.889^{* * *}, 148.357^{* * *}, 131.684^{* * *}\right)$ for $-2-, 2-, 24-, 48-h$ intervals and 7 days as well, respectively) (Table 2). On the other hand, when comparing the treated plots with its control at each inspection interval, nonsignificant differences were recorded $2 \mathrm{~h}$ before application and 2and 24-h post-treatment, while a significant difference was recorded at 48-h and 7-day post-treatment intervals (Table 2, Fig. 3). 
Table 2 Effect of indoxacarb and sorell $98 \%$ treatments on the population density of lacewing larvae and adults

\begin{tabular}{|c|c|c|c|c|c|c|c|}
\hline \multirow{2}{*}{$\begin{array}{l}\text { Inspection } \\
\text { intervals (h) }\end{array}$} & \multicolumn{6}{|l|}{ Treatments } & \multirow{2}{*}{$\begin{array}{l}\text { F value } 1 \\
(d f=3,12)\end{array}$} \\
\hline & Sulphur & Sulphur control & $T$ value $d f=6$ & Indoxacarb & $\begin{array}{l}\text { Indoxacarb } \\
\text { control }\end{array}$ & $T$ value $d f=6$ & \\
\hline & \multicolumn{6}{|c|}{ Chrysoperla larvae mean \pm SE } & \\
\hline-2 & $26.00 \pm 1.41 \mathrm{a} A \mathrm{~A}$ & $25.00 \pm 1.22 \mathrm{a} B C_{\mathrm{A}}$ & $00.535 \mathrm{NS}$ & $23.00 \pm 0.71 \mathrm{a} A \mathrm{~A}$ & $24.00 \pm 0.82 \mathrm{a} B \mathrm{~A}$ & $00.926 \mathrm{NS}$ & $01.429^{N S}$ \\
\hline+2 & $27.00 \pm 2.68 \mathrm{a} A \mathrm{~A}$ & $28.00 \pm 1.08 \mathrm{a} A B \mathrm{~A}$ & $00.346 N S$ & $19.00 \pm 1.08 \mathrm{~b} B$ в & $24.00 \pm 0.71 \mathrm{a} B \mathrm{~A}$ & $03.873^{* *}>$ & $06.533^{* *}$ \\
\hline+24 & $28.00 \pm 1.22 \mathrm{a} A \mathrm{~A}$ & $30.00 \pm 1.47 \mathrm{a} A \mathrm{~A}$ & $01.044^{\text {NS }}$ & $12.00 \pm 1.08 \mathrm{~b} C \mathrm{~B}$ & $28.00 \pm 1.08 \mathrm{a} A \mathrm{~A}$ & $10.474^{* *}>$ & $46.889^{* *}$ \\
\hline+48 & $29.00 \pm 0.41 \mathrm{a} A \mathrm{~A}$ & $24.00 \pm 2.08 b C_{B}$ & $04.330^{* *}>$ & $06.00 \pm 0.41 C D B$ & $22.00 \pm 1.08 \mathrm{~b} B \mathrm{~A}$ & $13.856^{* *}>$ & $148.375^{* *}$ \\
\hline+7 days & $28.00 \pm 0.41 \mathrm{a} A \mathrm{~A}$ & $15.00 \pm 0.82 \mathrm{~b} D \mathrm{~B}$ & $14.241^{* *}>$ & $03.00 \pm 1.08 \mathrm{C} E \mathrm{~B}$ & $15.00 \pm 1.08 \mathrm{~b} C_{\mathrm{A}}$ & $07.856^{* *}$ & $131.684^{* *}$ \\
\hline$F$ value $2(d f=4,15)$ & $0.591 \mathrm{NS}$ & $24.975^{* *}$ & & $85.560^{* *}$ & $24.429^{* *}$ & & \\
\hline \multirow[t]{2}{*}{$\%$ reduction } & \multicolumn{2}{|l|}{$+79.49 \%$} & & $-79.13 \%$ & & & \\
\hline & \multicolumn{3}{|c|}{ Chrysoperla adults mean \pm SE } & & & & \\
\hline-2 & $17.00 \pm 0.70 \mathrm{a} A \mathrm{~A}$ & $18.00 \pm 0.71 \mathrm{a} B \mathrm{~A}$ & $01.000 \mathrm{NS}$ & $17.00 \pm 1.08 \mathrm{a} A \mathrm{~A}$ & $17.00 \pm 0.96 a C_{A}$ & $01.039 \mathrm{NS}$ & $00.720 \mathrm{NS}$ \\
\hline+2 & $09.00 \pm 0.40 \mathrm{~b} B$ в & $30.00 \pm 1.47 \mathrm{a} A \mathrm{~A}$ & $13.748^{* *}>$ & $09.00 \pm 0.71 b B$ в & $21.00 \pm 1.08 \mathrm{a} A B \mathrm{~A}$ & $09.295^{* *}>$ & $57.600^{* *}$ \\
\hline+24 & $12.00 \pm 0.82 \mathrm{~b} B \mathrm{~B}$ & $33.00 \pm 1.78 \mathrm{a} A \mathrm{~A}$ & $10.726^{* *}>$ & $06.00 \pm 0.82 b C_{B}$ & $23.00 \pm 0.71 \mathrm{a} A \mathrm{~A}$ & $15.739^{* *}>$ & $165.143^{* *}$ \\
\hline+48 & $16.00 \pm 1.41 \mathrm{a} A \mathrm{~A}$ & $19.00 \pm 1.22 \mathrm{a} B \mathrm{~A}$ & $01.604 N S$ & $03.00 \pm 0.71 b D$ в & $18.00 \pm 1.78 \mathrm{a} B \mathrm{CA}_{\mathrm{A}}$ & $07.833^{* *}>$ & $40.909^{* *}$ \\
\hline+7 days & $18.00 \pm 1.41 \mathrm{a} A \mathrm{~A}$ & $12.00 \pm 1.08 b C_{B}$ & $03.372^{*}$ & $02.00 \pm 0.70 b D$ в & $11.00 \pm 0.41 \mathrm{a} D \mathrm{~A}$ & $11.023^{* *}>$ & $81.000^{* *}$ \\
\hline$F$ value $2(d f=4,15)$ & $13.406^{* *}$ & $45.471^{* *}$ & & $71.270^{* *}$ & $17.027^{* *}$ & & \\
\hline$\%$ reduction & $+58.82 \%$ & & & $-81.82 \%$ & & & \\
\hline
\end{tabular}

\footnotetext{
** highly significant, ${ }^{*}$ significant, NS, nonsignificant
}

In horizontal rows, means followed with different small letters are statistically different $(P>0.5)(F$ value 1$)$

In horizontal rows, per each treatment, means followed with different small capital letters are statistically different $(P>0.5)(T$ value $)$

In vertical columns, means followed with different capital Italic letters are statistically different $(P>0.5)(F$ value 2$)$

\section{Chrysoperla adult treatment}

Table 2 and Fig. 4 clarify the negative effects of both sulphur formulation and indoxacarb that were applied to control Aphis gossypii on the Okra field. As for sulphur treatment, the nonsignificant difference was recorded at $-2 \mathrm{~h}$ and $+48 \mathrm{~h}$ between the treated plot and its control, but statistically significant differences were recorded at $+2-,+24-h$ and 7-day post-treatment (Table 2, Fig. 4). Besides, there was a significant difference between inspection intervals $\left(F=13.406^{* *}\right)$, whereas an increment was recorded in the Chrysoperla adult population gaining $\approx 59 \%$ (Table 2).

The opposite results were found in indoxacarb by induced reduction percentage reached $\approx 82 \%$ (Table 2 , Fig. 4). Also, significant differences were recorded in almost all inspection intervals between treated and control plots (Table 2, Fig. 4).

\section{Paederus Treatments}

Paederus is one of the most important coleopteran predators, and it attacks many insect pests on either plant surface or underground when sulphur formulation or indoxacarb was applied to control aphids its population was negatively affected. Table 3 and Fig. 5 clarify this effect. It was observed that sulphur application reflects significant adverse reaction on the population mean number, especially at +2 and $+24 \mathrm{~h}$ post-treatment, and then increased once again (Table 3, Fig. 5); on another view, there were significant differences between the mean number throughout inspection intervals $\left(\mathrm{F}_{4,15}=10.453^{* *}\right)$, gaining $\approx 25 \%$ increment in the mean population count at the end of the experiment (Table 3 ). A significant difference was observed between treated plots and there control at all inspection periods except at the beginning and the end inspection times (Table 3, Fig. 5).

The similar pattern was noticed in indoxacarb treatment, but with some minor differences. The mean population number was diminished sharply to reach only three aphids at the end of the experiment, gaining $80 \%$ reduction, demonstrating significant difference between inspection intervals (Table 3 ). In addition, there were significant differences between treated plots and their control throughout the experiment period (7 days) (Table 3, Fig. 5).

\section{Aphid treatments}

After 7 days of aphid treatments, sulphur formulation and indoxacarb both had negative effect on the mean population number. Sulphur formulation caused $\approx \mathrm{a}$ $25 \%$ reduction in population, while indoxacarb caused a 


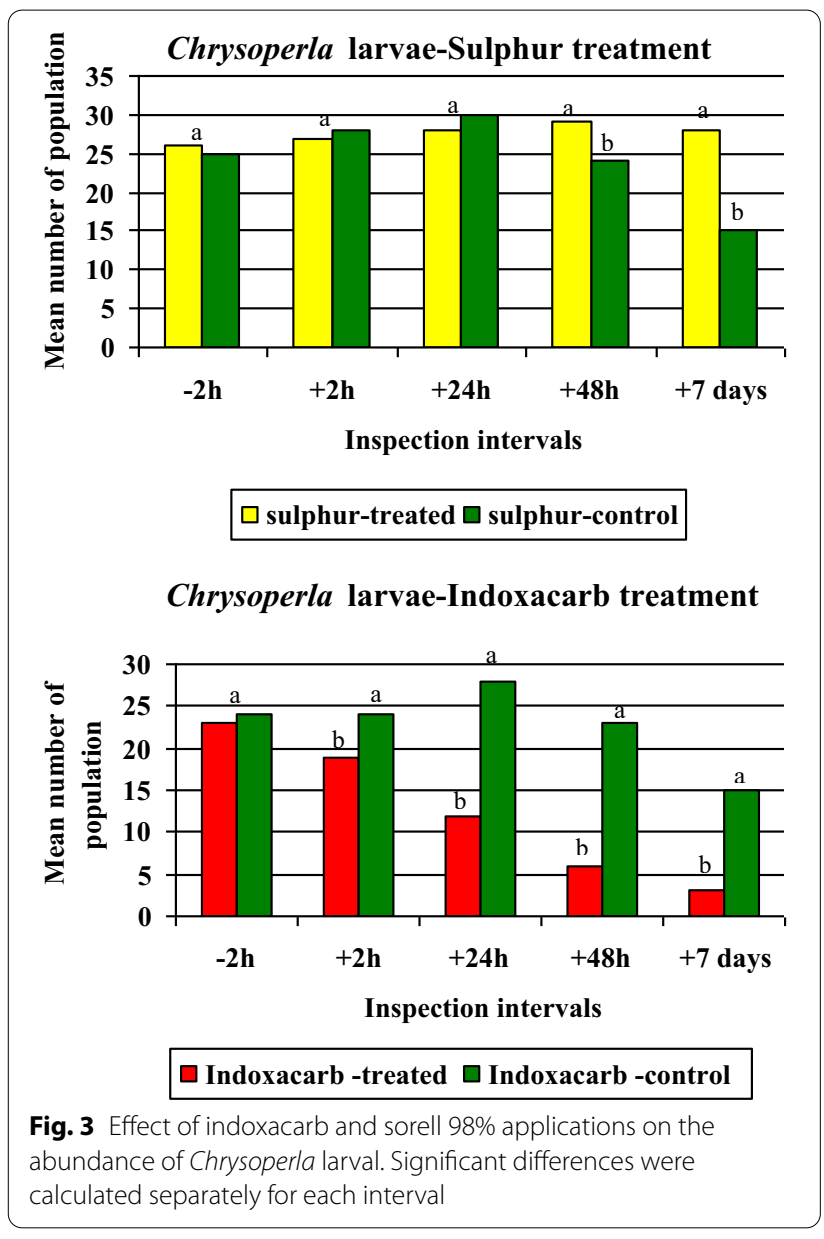

staggering $\approx a 97 \%$ drop in mean population number (end of the experiment) (Table 3, Fig. 6).

\section{Discussion}

\section{Coccinella undecimpunctata larval and adult treatments}

The application of sulphur formulation insecticide produced statistical differences between inspection times instance, as well as between treated and control plots. Data in Table 1 demonstrate that applying both tested insecticides to control aphids negatively affected the density of the C. undecimpunctata prevailing population. All treated plots exhibit highly significant differences between inspection time intervals, and also between a treatment and its control plots.

In case indoxacarb was applied, the statistical analysis indicates a highly significant difference was noticed in mean numbers recorded between inspection time interval and when comparing treated and control plots.

These obtained results matched those of Cabral et al. (2011) when they evaluated the effects of pirimicarb and pymetrozine on the voracity of fourth instar larvae and adults of $C$. undecimpunctata. Results were agreed with

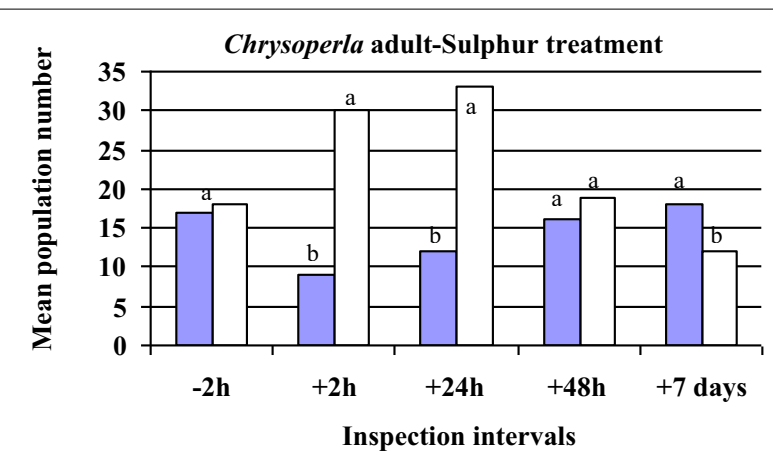

$\square$ sulphur-treated $\square$ sulphur-control

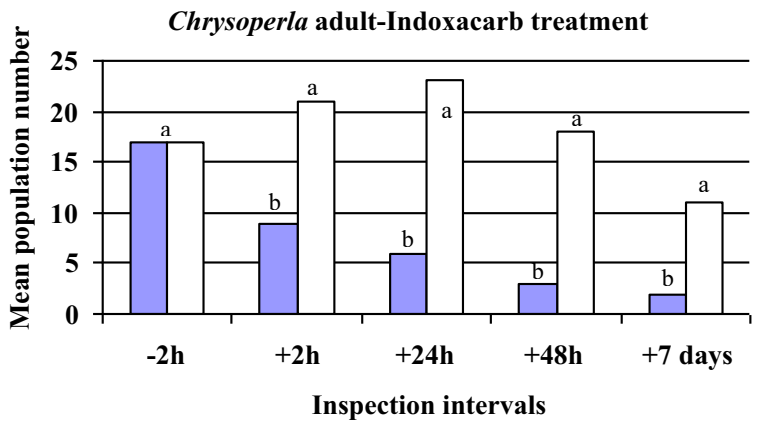

$\square$ Indoxacarb-treated $\square$ Indoxacarb-control

Fig. 4 Effect of indoxacarb and sorell $98 \%$ applications on the abundance of Chrysoperla adults. Significant differences were calculated separately for each interval

those findings reported by Matter et al. (2018 and 2019), Gesraha and Ebeid (2019), Gesraha et al. (2019) when they applied sulphur formulation to study its effects on C. undecimpunctata larvae and adults. The obtained results matched those of Jalali et al. (2009) when they evaluated the toxicity of some insecticides to the twospot ladybird, Adalia bipunctata in a laboratory study, and those of Roubos et al. (2014) when they conducted a series of bioassays to determine the relative toxicities and residual activities of insecticides labelled for use in blueberry (Vaccinium corymbosum L.) on natural enemies, to identify products with low toxicity or short-duration effects on biological control agents. They evaluate 14 insecticides and four commercially available natural enemies including ladybeetle, Hippodamia convergens Guérin-Méneville. Results were in accordance with that reported by Garzón et al. (2015) who tested the toxicity and sublethal effects of flonicamid, flubendiamide, metaflumizone, spirotetramat, sulfoxaflor and deltamethrin on the natural enemies Chrysoperla carnea and ladybeetle, Adalia bipunctata that were toxic to the tested natural enemies. Liu et al. (2016) then examined the toxicity of nine insecticides on four natural enemies of Spodoptera 
Table 3 Effect of indoxacarb and sorell $98 \%$ treatments on the population density of Paederus and Aphis movable stages

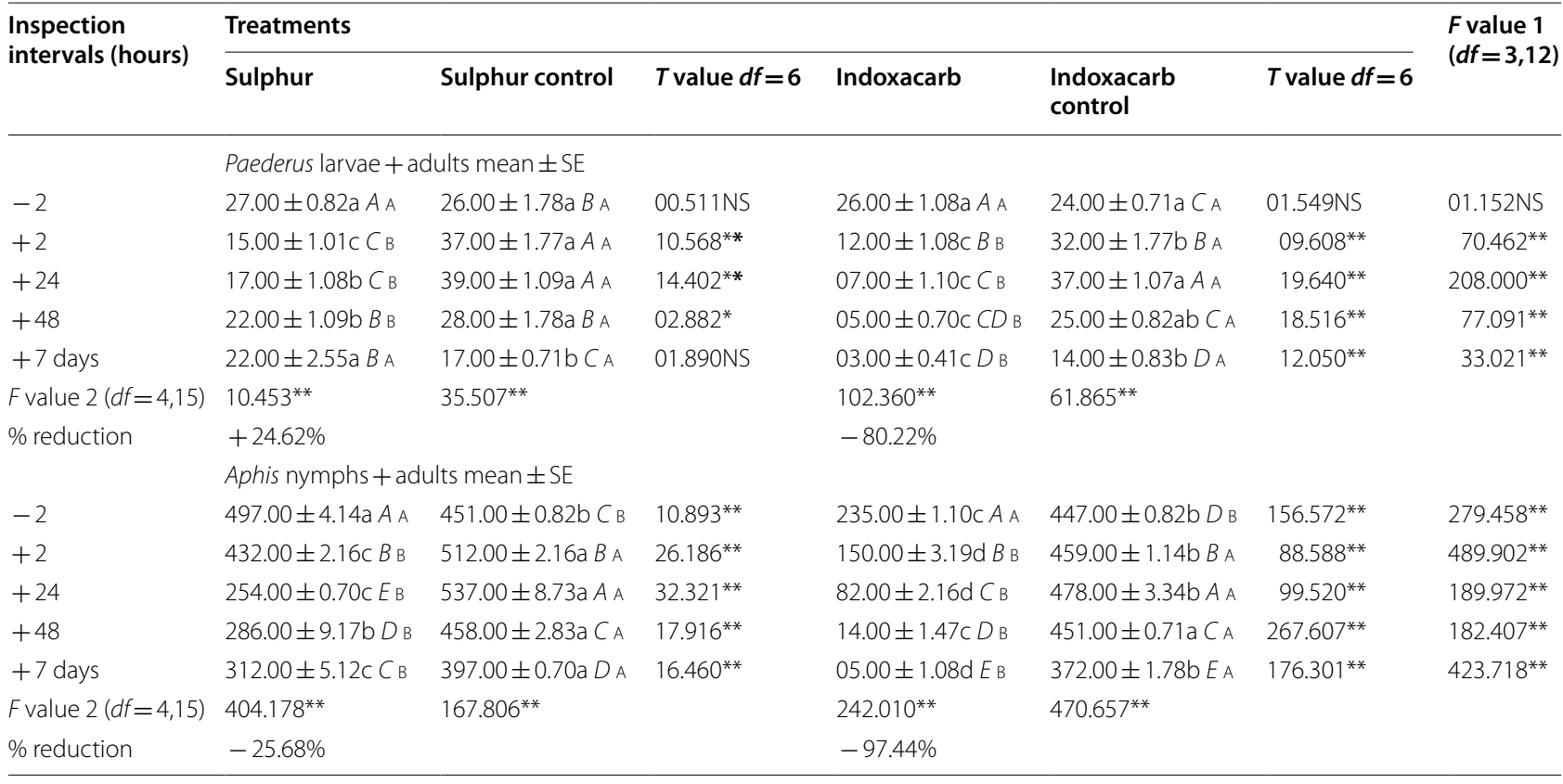

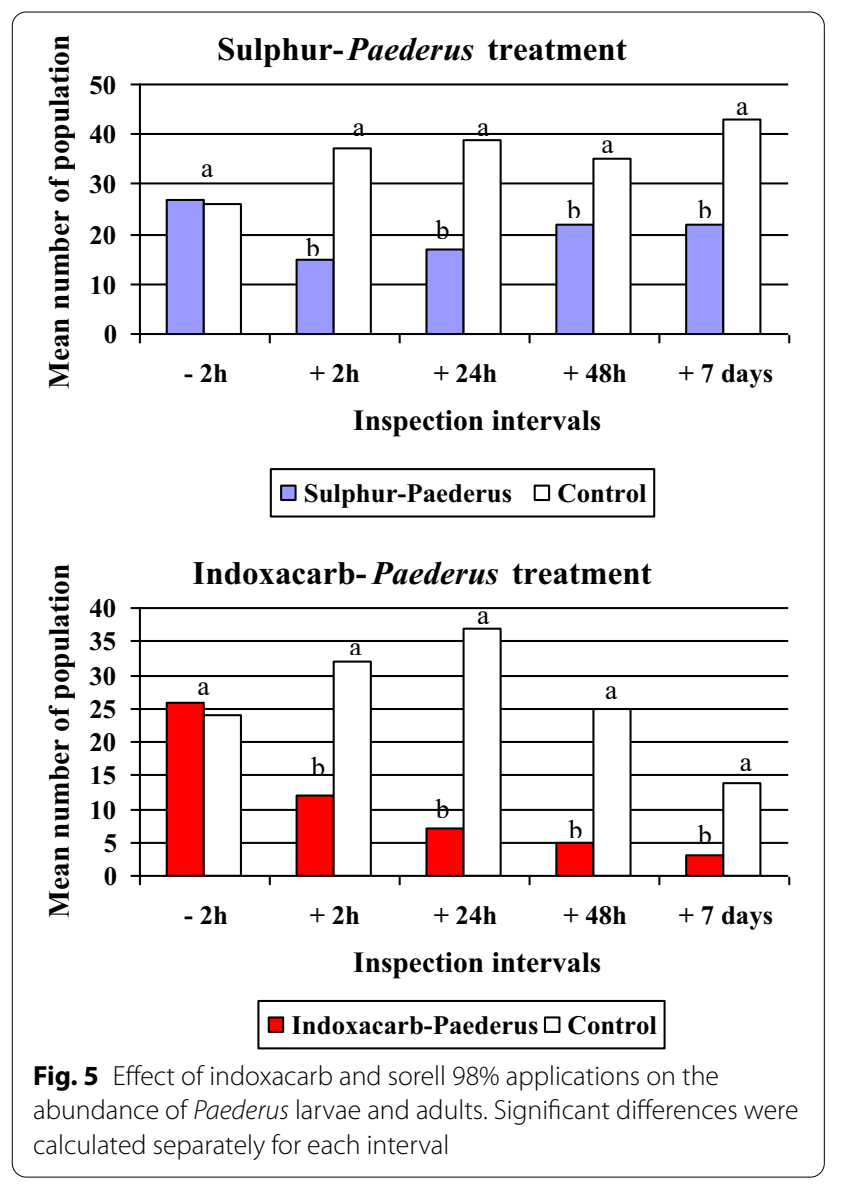

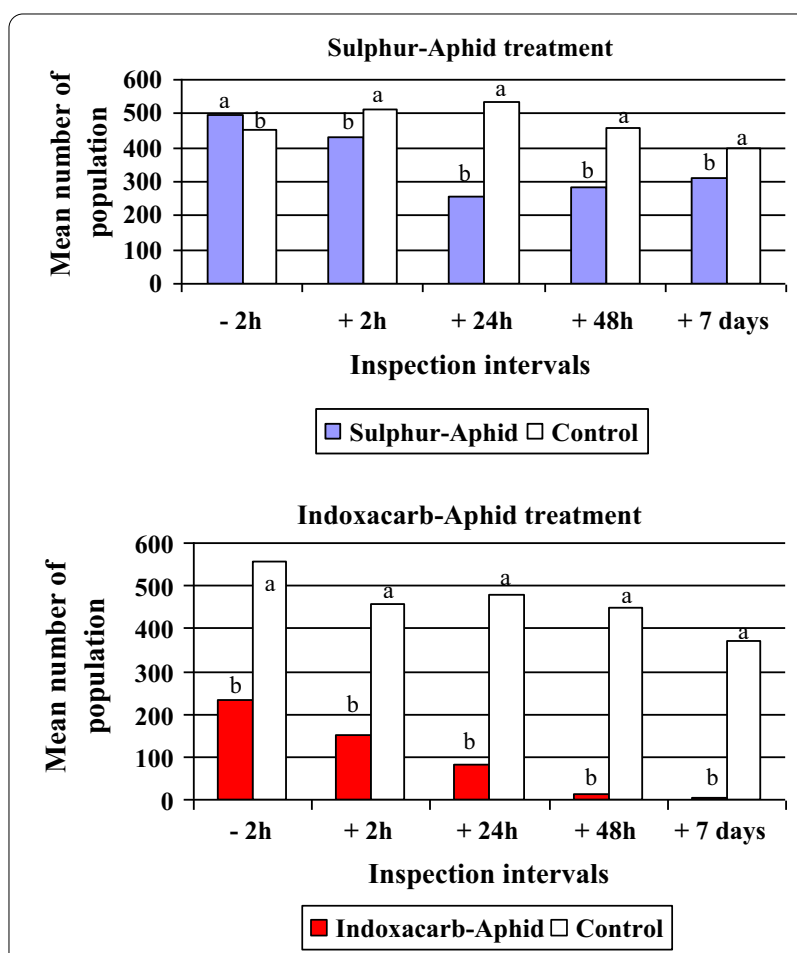

Fig. 6 Effect of indoxacarb and sorell 98\% applications on the abundance of aphid nymphs and adults. Significant differences were calculated separately for each interval 
exigua. Our results were confirmed by Galvan et al. (2005, 2006) when applied spinosad and indoxacarb, where they reported that the tested insecticides are more toxic to lepidopteran pests than to the ladybird, Harmonia axyridis.

\section{Chrysoperla carnea larval and adult treatments}

As for Lacewings predator, it was observed that treated C. carnea larvae or adults reflect the incognizant difference between inspection time intervals and between treated and control plots at $-2 \mathrm{~h},+2 \mathrm{~h}$ and $+24 \mathrm{~h}$ of treatment, but significant differences were observed between each treatment and its control plots after $48 \mathrm{~h}$ and after 7 days. Indoxacarb induced highly significant differences in the case of each treated and control plots or between inspection time intervals, leading to about $80 \%$ reduction in population mean number. Data illustrated in (Table 2 and Fig. 4) clarify that the negative effects induced by applying the sulphur-tested insecticide for controlling aphid population resulted in highly significant differences either between inspection time intervals or between treated and control plots.

The abovementioned obtained results matched those reported by Golmohammadi and Hejazi (2014) when they evaluated the toxicity of endosulfan, imidacloprid and indoxacarb on C. carnea adults under the laboratory conditions. They reported that males were more sensitive than females to all three insecticides. The adult stage was very sensitive to indoxacarb, imidacloprid and endosulfan. Hence, they recommended that these insecticides should not be applied when the density of adults is high in the field. Also, the results were following that reported by Roubos et al. (2014) when they conducted a series of bioassays to determine the relative toxicities and residual activities of insecticides labelled for use in blueberry (Vaccinium corymbosum L.) on natural enemies, to identify products with low toxicity or short-duration effects on biological control agents. In total, 14 insecticides were evaluated and four commercially available natural enemies including Chrysoperla rufilabris [Burmeister]. Results matched those of Liu et al. (2016) when they examined the toxicity of nine insecticides on four natural enemies of Spodoptera exigua. Also, our results matched the findings of Wanumen et al. (2016) who tested and compared seven insecticides including indoxacarb on some natural enemies comprising C. carnea and reported adverse effects on the tested natural enemies. Also, matched with Barros et al. (2018) who tested some old and new insecticides to control cotton pests, and to evaluate these insecticides against prevailing natural enemies including Chrysoperla externa Hagen, they reported that all tested natural enemies exhibited $100 \%$ mortality. Our findings matched those of Khan et al. (2015) who tested the residual effects of four insecticides against $C$. carnea different stages, showing the adverse effects of these tested materials on this important natural enemy. Results were agreed with those reported by Gesraha and Ebeid (2019), Gesraha et al. (2019) who reported the adverse impact on this predator. Also, our results matched those reported by Rugno et al. (2019) when they studied the impact of 11 insecticides on the predator Chrysoperla cubana from first instar larvae to adults; he reported that showing the negative effects of these tested insecticides.

\section{Paederus treatments}

Paederus as one of the most important coleopteran predators was badly affected when both tested insecticides were applied for aphid control. There were highly significant differences between its mean number of population at each inspection time interval especially after 2 and $24 \mathrm{~h}$, and also, between treated and control plots. Indoxacarb was harmful to this beetle inducing the same trend between treated and control plots. These findings were in accordance with Bong et al. (2013) when they evaluated the contact toxicity of four insecticide formulations applied against the adult rove beetle, Paederus fuscipes Curtis; they reported that all tested insecticides were highly toxic. Zhang et al. (2016) evaluated the contact and fumigant toxicity as well as repellent activity of ten plant essential oils carried out against Paederus fuscipes Curtis adults and reported that almost all tested materials were highly toxic to the predator adults. Also, matched with that reported by Khan et al. (2018) when examined the use of pesticides in rice fields. The rove beetle (Paederus fuscipes), which is an important predator of the brown planthopper (Nilaparvata lugens) in rice ecosystems, was tested to investigate acute and chronic effects of emamectin benzoate. The results from this study show that the tested material had significant adverse effects on the second instar developmental time of $P$. fuscipes compared with that of the control. They conclude that more attention should be paid to the use of this chemical as part of integrated pest management strategies. Our findings matched those reported by Feng et al. (2019) for his work on Paederus fuscipes Curtis treated with three insecticides; they reported that the tested materials reflect the bad impact on all physiological parameters on this predator.

\section{Aphid treatments}

Dealing with aphid treatments, it was observed that either sulphur formulation or indoxacarb insecticide negatively affected the population of aphid, where indoxacarb proved more toxicity than sulphur formulation inducing about $97 \%$ reduction in the aphid population but sulphur inducing only about $26 \%$. Our obtained 
results were following that reported by several authors such as Farag (1995) who examined the effect of some predators and parasitoids to control Aphis spp. population and Zaki et al. (1999) who released two predators to control the aphid population in greenhouse and open fields. The obtained results matched those of Bostanian and Akalach (2004) who examined the toxicity of some insecticides, including indoxacarb, under laboratory conditions, to control aphid population and to study their adverse effects on some natural enemies. They reported that indoxacarb had no effects on aphid mummy, but affected the movable stages. Our obtained findings were accordance with Awasthi et al. (2013) for his work deals with studying the comparative toxicity of some commonly used insecticides to cotton aphid and their safety to predatory coccinellids.

Lastly, the obtained results matched those reported by Dutta et al. (2016) on their field study to evaluate four insecticides against mustard aphid and their toxicity to coccinellid beetles. They found that among the treatments, azadirachtin 1EC appeared to be safest to coccinellid beetles, while indoxacarb $145 \mathrm{SC}$ was found to be toxic. Matched with the suggested findings of Zuo et al. 2016 on their work on the sublethal effects of indoxacarb and beta-cypermethrin on Rhopalosiphum padi (Hemiptera: Aphididae) under laboratory conditions.

\section{Conclusion}

It could be concluded that indoxacarb is more hazardous towards different natural enemies prevailing naturally in open fields at anywhere season round the year. Care must be in consideration when we choose or recommend and select some insecticides to kill or to eradicate the pest and simultaneously conserve the natural enemies.

\section{Acknowledgements}

The authors are very grateful to all colleges, their valuable assistance and advice and much appreciative of all people's help in fieldwork.

\section{Authors' contributions}

MAG suggested the research idea, designed the experiments, collecting data field, statistically analysed the data, wrote the manuscript, reviewed data, managed tables, edited and approved the manuscript. ARE approved the suggested research idea, made the experiments, collected and recorded data field, prepared tables, assisted in writing and approved the manuscript. All authors read and approved the final manuscript.

\section{Funding}

The experimental work is funded by authors.

\section{Availability of data and materials}

All data and materials are available.

\section{Ethics approval and consent to participate} Not applicable.

\section{Consent for publication}

Not applicable.

\section{Competing interests}

The authors declare that they have no competing interests.

Received: 10 June 2020 Accepted: 6 December 2020

Published online: 07 January 2021

\section{References}

AwasthiNS BUP, Patil SR, Lande GK (2013) Comparative toxicity of some commonly used insecticides to cotton aphid and their safety to predatory coccinellids. The Bioscan 8(3):1007-1010

Azma M, Mirabzadae A (2004) Issues on different aspects of applying natural enemies for biological control of insect pests. Sepehr Publication, Tehran

Barros EM, da Silva TCSA, Torres JB, Rolim GG (2018) Short-term toxicity of insecticides residues to key predators and parasitoids for pest management in cotton. Phytoparasitica 46:391-404

Bong LJ, Neoh KB, Jaal Z, Lee CY (2013) Contact toxicity and residual effects of selected insecticides against the adult Paederus fuscipes (Coleoptera: Staphylinidae). J Econ Entomol 106(6):2530-2540

Bostanian JN, Akalach M (2004) The contact toxicity of indoxacarb and five other insecticides to Orius insidiosus (Hemiptera: Anthocoridae) and Aphidius colemani (Hymenoptera: Braconidae), beneficial used in the greenhouse industry Pest Manag Sci 60:1231-1236.

Cabral S, Garcia P, Soares AO (2008) Effects of pirimicarb, buprofezin and pymetrozine on survival, development, and reproduction of Coccinella undecimpunctata (Coleoptera: Coccinellidae). Biocontrol Sci Tech 18:307-318

Cabral S, Soares AO, Garcia P (2009) Predation by Coccinella undecimpunctata (Coccinellidae) on Myzus persicae: effect of prey density. Biol Control 50:25-29

Cabral S, Soares AO, Garcia P (2011) Voracity of Coccinella undecimpunctata: effects of insecticides when foraging in a prey/plant system. J Pest Sci 84:373-379

Carnard M, Principi MM (1984) Life histories and behavior. In: Carnard M, Semeria Y, News TR (Eds) Biology of Chrysopidae (Series Entomologica), pp. 57-134. Junk Publishers, The Hauge.

Croft AB (1990) Arthropod biological control agents and pesticides. Wiley, New York

Duncan DB (1955) Multiple ranges and multiple F-test. Biometrics 11:1-42

Dutta NK, Alam SN, Mahmudunnab M, Khatun MF, Kwon YJ (2016) Efficacy of some new generation insecticides and a botanical against mustard aphid and their toxicity to coccinellid predators and foraging honeybees. Bangladesh J Agric Res 41(4):725-734

ElHag ETA (1992) Potential role of indigenous Coccinellidae in regulation of aphid populations in Central Arabia wheat fields. Trop Pest Manag 38(4):425-430

Elhag ETA, Zaitoon AA (1996) Biological parameters for four coccinellid species in central Saudi Arabia. Biol Control 7:316-319

Farag, NA (1995) Studies on the biological control of whiteflies and Aphids on some vegetable crops. Ph.D. Thesis, Environmental Science- Agricultural Department, Ain Shams University, Cairo, Egypt

Feng WB, Bong LJ, Neoha DSM (2019) Effect of imidacloprid exposure on lifehistory traits in the agricultural generalist predator Paederus beetle: Lack of fitness cost but strong hormetic effect and skewed sex ratio. Ecotoxicol Environ Saf 174:390-400

Freed RD (1985) MSTAT-C Statistical Package, Version 2.0.0. Crop and Soil Science Department, Michigan State University, East Lansing

Galvan TL, Koch RL, Hutchison WD (2005) Effects of spinosad and indoxacarb on survival, development, and reproduction of the multicolored Asian lady beetle (Coleoptera: Coccinellidae). Biol Control 34(1):108-114

Galvan TL, Koch RL, Hutchison WD (2006) Toxicity of indoxacarb and spinosad to the multicolored Asian lady beetle, Harmonia axyridis (Coleoptera: Coccinellidae), via three routes of exposure. Pest Manage Sci 62(9):797-804

Garzón A, Medina P, Amor F, Viñuela E, Budia F (2015) Toxicity and sublethal effects of six insecticides to last instar larvae and adults of the biocontrol agents Chrysoperla carnea(Stephens) (Neuroptera: Chrysopidae) and Adalia bipunctata (L.) (Coleoptera: Coccinellidae). Chemosphere 132:87-93

Gesraha MA, Ebeid AR (2019) Impact of sulfur dust application on the abundance of two important coccinellid predators in marrow fields. Bull Nat Res Cent Egypt 43(34):1-7 
Gesraha MA, Ebeid AR, El-Rahman AAA (2019) Do the diversity of plants and sulphur application influence the population fluctuation of insect predator? Bull Nat Res Cent Egypt 43(159):1-8

Golmohammadi Gh, Hejazi M (2014) Toxicity and side effects of three insecticides on adult Chrysoperla carnea (Neu: Chrysopidae) under laboratory conditions. J Entomol Soc Iran 33(4):23-28

Henderson CF, Tilton EW (1955) Tests with acaricides against the brow wheat mite. J Econ Entomol 48:157-161

Jalali MA, Van Leeuwen T, Tirry L, De Clercq P (2009) Toxicity of selected insecticides to the two-spot ladybird Adalia bipunctata. Phytoparasitica 37:323-326

Khan MM, Nawaz M, Hua H, Cai W, Zhao J (2018) Lethal and sublethal effects of emamectin benzoate on the rove beetle, Paederus fuscipes, a non-target predator of rice brown planthopper, Nilaparvata lugens. Ecotoxicol Environ Saf 165:19-24

Khan SZ, Ullah F, Khan S, Khan MA, Khan MA (2015) Residual effect of insecticides against different stages of green lacewing, Chrysoperla Carnea (Neuroptera: Chrysopidae). J Entomol Zool Studies 3(4):114-119

Liu Y, Li X, Zhou C, Liu F, Mu W (2016) Toxicity of nine insecticides on four natural enemies of Spodoptera exigua. Sci Rep 1-9(6):39060. https://doi. org/10.1038/srep39060

Matter MM, Ebeid AR, Marei SS, El-Fandary OO, Farag NA, Gesraha MA (2019) Effect of sulphur dust application on some insect predators naturally occurring in Okra fields. Biosci Res 16(2):1153-1160

Matter MM, El-Rahman AAA, Marei SS, El-Fandary OO, Farag NA, Gesraha MA (2018) Impact of the application of sulphur formulation on the abundance and activity of insect predators naturally existing in marrow fields. Asian J Biol 7(1):1-8

Meena BL, Dadhich SR, Kumawat RL (2002) Efficacy of some insecticides against ladybird beetle, Coccinella septumpunctata L. feeding on fenugreek aphid, Acyrthosiphon pisum (Harris). Ann Biol 18:171-173

Metcalf RL (1986) The ecology of insecticides and chemical control of insects. In: Kogan M (ed) Ecological theory and integrated pest management practice. Wiley, New York, pp 251-297
Moura R, Garcia P, Cabral S, Soares AO (2006) Does pirimicarb affect the voracity of the euriphagous predator, Coccinella undecimpunctata L.? Biol Control 38:363-368

Roubos CR, Rodríguez SC, Holdcraft R, Mason KS, Isaacs R (2014) Relative toxicity and residual activity of insecticides used in blueberry pest management: mortality of natural enemies. J Econ Entomol 107(1):277-285

Rugno GR, Zanardi OZ, Parra JRP, Yamamoto PT (2019) Lethal and Sublethal Toxicity of Insecticides to the Lacewing Ceraeochrysa Cubana. Neotrop Entomol 48:162-170

Tawfik MFS, El-Sherif SI, Abouzied NH (1976) Population fluctuations of the rove-beetle Paederus alfierii Koch. (Col., Staphylinidae) in maize, cotton and clover fields in Giza region. J Appl Entomol 80(1-4):75-83

Wanumen AC, Carvalho GA, Medina P, Vinuela E, Adan A (2016) Residual acute toxicity of some modern insecticides toward two mirid predators of tomato pests. J Econ Entomol 109(3):1079-1085

Yadav DP (1989) Integrated pest management on Mustard. Annal Agric Res 22:429-431

Zaki FN, El-Shaarawy MF, Farag NA (1999) Release of two predators and two parasitoids to control aphids and whiteflies. J Pest Sci 72:19-20

Zhang Q, Wu X, Liu Z (2016) Primary screening of plant essential oils as insecticides, fumigants, and repellents against the health pest Paederus fuscipes (Coleoptera: Staphylinidae). J Econ Entomol 109(6):2388-2396

Zuo Y, Wang K, Lin F, Li Y, Peng X, Piñero JC, Chen M (2016) Sublethal effects of indoxacarb and beta-cypermethrin on Rhopalosiphum padi (Hemiptera: Aphididae) under laboratory conditions. Florida Entomologist 99(3):445-450. https://doi.org/10.1653/024.099.0316

\section{Publisher's Note}

Springer Nature remains neutral with regard to jurisdictional claims in published maps and institutional affiliations.

\section{Submit your manuscript to a SpringerOpen ${ }^{\circ}$ journal and benefit from:}

- Convenient online submission

- Rigorous peer review

- Open access: articles freely available online

- High visibility within the field

- Retaining the copyright to your article

Submit your next manuscript at $\boldsymbol{\nabla}$ springeropen.com 